\title{
Transkriptom Verisi ve Omik Araçları Kullanılarak Otoimmün Hastalıklar ile İnsan Bağırsak Mikrobiyotası Arasındaki İlișkinin Analizi
}

\author{
Tuba SEVIMMOĞLU \\ Üsküdar Üniversitesi, Mühendislik ve Doğa Bilimleri Fakültesi, Biyomühendislik Bölümü, 34662, İstanbul \\ (ORCID: https://orcid.org/0000-0003-4563-3154)
}

(Alınıș / Received: 30.07.2018, Kabul / Accepted: 28.01.2019, Online Yayınlanma / Published Online: 16.04.2019)

Anahtar Kelimeler
Otoimmünite,
Psoriazis,
Atopik dermatit,
Romatoid artrit,
Metabolit,
İnsan bağırsak mikrobiyotası
Özet: İnsan bağırsak mikrobiyotası ile insan hastalıkları arasındaki ilişkinin anlamlandırılabilmesi konusunda yapılan çalışmalar yakın zamanda ivme kazanmıştır. Bunun sebebi insan mikrobiyomunun hastalıklı ve sağlıklı hallerdeki işlevi ve yapısı hakkında daha çok bilgiye sahip olunması ve ilişkili mikrobiyal toplulukların genomlarının DNA diziliminin doğru belirlenmesi şeklinde açıklanabilir. Yine de bu konuda çok fazla çalışma bulunmamaktadır. Mevcut çalışmada üç önemli otoimmün hastalık olan Psoriazis, Romatoid Artrit ve Atopik Dermatit'in, omiks araçları ile önce transkripsiyon regülasyonu metabolik ağa entegre edilmiş daha sonra ise bu hastalıkların insan bağırsak mikrobiyotası ile arasındaki bağlantı ortaya çıkarılmıştır. Elde edilen sonuçlara göre seçilmiş olan hastalıklar ile ilgili ortak mikrobiyal türler mevcuttur. Bunlar yoğun olarak Firmicutes, Deltaproteobacteria, Bacteriodetes ve Actinobacteria filumundaki türlerdir. Bu çalışmada bir başka dikkat çeken husus ise Tenericutes filumunun mikrobiyal türlerinin Atopik dermatit ve Romatoid artritte yoğun olarak görüldüğü fakat Psoriaziste çok fazla çeşitlilik göstermediğidir. Bu sonuçlar insan bağırsak mikrobiyotasının kompleks otoimmün hastalıklarda bir rolünün olduğunu göstermektedir. Yapılan bu çalışma bir hastalığın mekanizmasını anlayabilmek için sadece genler ve proteinler değil bunların yanında metabolitler, mikrobiyota ve patojen grupların da detaylıca incelenip analiz edilmesi gerektiğini ortaya koymaktadır.

\section{Analysis of Autoimmune Diseases-Human Gut Microbiota Association Using Transcriptome Data and Omic Tools}

\section{Keywords}

Autoimmunity,

Psoriasis,

Atopic dermatitis,

Rheumatoid arthritis,

Metabolite,

Human gut microbiota

\begin{abstract}
Recent advances in omic analyses and the accurate determination of DNA sequencing of genomes of human-related microbial communities have helped increase the knowledge of the function and structure of human microbiota in diseased and healthy states. However there is still not much work done in this regard. In this study, three important autoimmune diseases, Psoriasis, Rheumatoid Arthritis and Atopic Dermatitis were selected. Firstly the transcriptional regulation for these diseases were integrated with metabolic pathways using omic tools. Secondly the link between human intestinal microbial species and these diseases were revealed. The results have shown that there is a mutual group of microbial species among the selected diseases. These are intensively species of Firmicutes, Deltaproteobacteria, Bacteriodetes and Actinobacteria phyla. Another noteworthy aspect of this study is that the microbial species of the Tenericutes phyla are intensely present in atopic dermatitis and rheumatoid arthritis but not in psoriasis. These results display that human gut microbiota has a role in complex autoimmune diseases. This study showed that not only genes and proteins, but also metabolites, microbiota and pathogen groups should be examined and analyzed in detail in order to comprehend the mechanism of a disease.
\end{abstract}




\section{Giriş}

İnsan mikrobiyomu, insanlar üzerinde ve içinde yaşayan mikroorganizmaların tam bir dizisi (mikrobiyota) veya bir insanın genetik portresine veya metagenomuna katkıda bulunan mikrobiyal genomların toplamı şeklinde tarif edilebilir. İnsan mikrobiyomunun tanımı konusunda terminoloji ile ilgili sıkıntılar nedeniyle bir karmaşıklık vardır. Örneğin "mikrobiyota" (insanlarla ilişkili mikrobiyal takson) ve "mikrobiyom" (bu mikropların ve bunların genlerinin kataloğu) sıklıkla birbirinin yerine kullanılır. İnsan mikrobiyomu konusundaki çalışmalar 1680'li yıllarda başlamış olmasına rağmen gelişmeler 2007'den sonra, insan vücudunda bulunan mikrobiyal toplulukları karakterize etmek ve her bir mikroorganizmanın sağlık ve hastalıktaki rolünü tanımlanması için başlatılan İnsan Mikrobiyomu Projesi'nin (HMP) yürürlüğe girmesiyle ivme kazandı [1]. Son yıllarda özellikle bağırsak mikrobiyotasının insan sağlığı ve hastalığındaki rolü daha çok anlaşılmaya başlanmıştır. Yapılan araştırmalar, mikrobiyotaların, izole olarak var olmaktan ziyade, bağışıklık sisteminin gelişimi, sinir sistemi fonksiyonu ve metabolizma dahil olmak üzere, insan fizyolojisinin çoklu yönlerini ortak düzenleyen "holobiont" olarak adlandirlan kompleks bir meta-organizma oluşturduğunu vurgulamaktadır. Farklı mikrobiyota konfigürasyonları metabolitlerin üretilmesine, değişmesine ve bozulmasına sebebiyet vererek konakçının metabolik kapasitelerine fonksiyonel bir tamamlama sağlar; örneğin, konakçı (host) tarafından parçalanamayan kompleks proteinler ve karbonhidratlar, mikrobiyal topluluk tarafından metabolize edilebilir [2]. Bu sebeple metabolitlerin insan bağırsak mikrobiyotası ile olan bağlantısı da hastalıkların sebeplerinin daha detaylı anlaşılabilmesi için elzemdir. İnsan Bağırsak mikrobiyotası bağırsakta ve/veya buradaki metabolitler üzerinde yaşayan farklı mikroorganizmaların tamamı olarak tanımlanır. İnsan bağırsağında binin üzerinde mikrobiyal tür kolonize şekilde yaşamaktadır. Yapılan araştırmalara göre insan bağırsak mikrobiyotasının dengesinin bozulması ve bileşiminde meydana gelen değişiklikler psoriazis ve atopik dermatit gibi otoimmün hastalıklara neden olmaktadır. [3, 4].

İnsan bağırsak mikrobiyotası, mikroorganizmalar ve konakçı tarafından üretilen endojen bileşiklerin yanı sıra, kolona ulaşan eksojen sindirilmemiş diyet bileşenlerinin anaerobik fermentasyonundan son derece çeşitli bir metabolit repertuar üretir. Konak ve mikroorganizmalar arasındaki mukozal ara yüzü oluşturan tek epitelyal hücre tabakası nedeniyle mikrobiyal metabolik ürünler konakçı hücrelere erişir ve bunlarla etkileşime girer ve böylece immün tepkiyi etkiler ve hastalık riskini arttırır [5].

Bir hastalığın oluşumunda rol oynayan olası gen veya gen kümelerinin (protein veya protein setleri) araștırılmasında gen ekspresyon profili, proteinlerin fiziksel etkileşimlerinin haritalanması ve bu proteinlerin yer aldığı sinyal yolakları bize yol gösterebilir. Bu verilerin yardımıyla biyolojik bir yolun işlevsizliğinin ardındaki mantıkta yorumlanabilir. Biyolojik ağlar ile biyolojik ve gelişimsel belirteçler oluşturmak için çeşitli veri kümelerini entegre etmek, işlevsel genom araçlarını kullanmanın etkili yollarındandır [6]. Ancak biyolojik süreçler genellikle karmaşık bir şekilde birbirine bağlanmış makromolekül ve metabolit ağları olarak görülmeli ve bu şekilde analiz edilmelidir. İnsan mikrobiyom sisteminin metabolitleri, metagenomfenotip ilişkileri için bir köprü teșkil eder [7]. Dolayısıyla gen-hastalık bağlantılarının analizinin yanı sıra hastalıkta belirteç olabilecek raportör metabolitlerin analizi de hastalığın oluşumunu anlamamıza ve bu hastalığın tedavisi için çözümler üretebilmemize yardımcı olur [8]. Yani bir hastalığın yapısını tam olarak anlayabilmek için genler, proteinler, etkileşim ağları, sinyal yolakları, metabolitler ve mikrobiyal türler ve bunlarm arasındaki etkileșimler bir bütün olarak ele alınmalıdır. Ancak bu yolla hastalıklar için uygun bir tedavi yöntemi ortaya çıkarılabilir.

Otoimmün hastalıklar, vücudun kendi antijenlerine karşı immünolojik tolerans kaybından kaynaklanan kronik durumlardır. Otoimmün hastalıkların gelişimine katkıda bulunan genetik ve çevresel faktörler arasındaki ilişkiler hala belirsizdir. Bu faktörlere örnek olarak modern yaşam tarzı, diyet, antibiyotik kullanımı ve hijyen gibi örnekler verilebilir. İnsan bağırsak mukozal bölgeleri çoğunlukla çevreden etkilenir ve buradaki milyonlarca yerleşik mikrobiyota sürekli olarak bağışıklık sistemine ve metabolizmaya şekil vermektedir [3]. Otoimmün bir hastalık olan Psoriazis, deri lezyonları ve eklem ağrısı olarak kendini gösteren, yaygın, kompleks, multigenik, enflamatuar bir hastalıktır. Dünya nüfusunun \% 2-3'ünü etkiler. Travma veya cerrahi sonrası, duygusal sıkıntı ya da çevresel, immünolojik veya genetik tetikleyicilerin bir sonucu olarak ortaya çıkabilir [9]. Bir başka otoimmün hastalık olan Romatoid artrit (RA), eklem ve yapısal kemik hasarına yol açan sinoviyal eklemlerin kronik inflamasyonu ve tahribi ile kendini gösteren kompleks bir hastalıktır. Hastalığın ilerlemesinde genetik ve çevresel faktörler yer almaktadır [10]. Hastalığın ilerlemesi, hastanın yaşam kalitesini etkileyen ağrı, sertlik ve sakatlığa neden olur. RA, insan lökosit antijeni (HLA) kompleksinin genleri ile ilişkili olmasına rağmen, hastalığın moleküler mekanizması tam olarak anlaşılamamıştır ve dolayısıyla hastaların uygun tedavisi konusunda çalışmalar devam etmektedir [11]. Atopik dermatit (AD) kronik, inflamatuar bir deri hastalığıdır. Son yıllarda yapılan çalışmalarla AD'nin otoimmün bir hastalık olduğu kanıtlanmıştır [12]. AD'nin patogenezinde genetik, immünolojik faktörler, epidermal bariyer anormallikleri ve çevre gibi çeşitli faktörler vardır; Bununla birlikte, hastalığı yöneten hücresel ve moleküler mekanizmalar hala tam olarak anlaşılamamıştır. AD'deki antimikrobiyal peptitlerin 
eksikliğinin yanı sıra, hücre aracılı immünitenin azalması, hastaların yaşam kalitesini olumsuz etkileyen bakteriyel ve viral enfeksiyonlara neden olmaktadir [13].

Bu çalışmada birer otoimmün hastalık olan Psoriazis, Romatoid Artrit ve Atopik Dermatit'in farklı gen ekspresyonuna sahip genlerden oluşan gen listeleri kullanılarak raportör metabolit analizi yapılmış ve bu metabolitlerin zenginleştirme çalışması yapılarak istatistiksel olarak anlamlı bulunan metabolik yolaklar ortaya çıkarılmıștır. Daha sonra bu raportör metabolitler ile ilintili bağırsak mikrobiyotası listelenmiş ve incelenen hastalıklar için ortak bir mikrobiyal tür ve grup listesi oluşturulmuştur.

\section{Materyal ve Metot}

\section{1. Çalışmada Kullanılan Veri Setleri}

Yapılan çalıșmada, incelenen hastalıklar ile ilgili Gene Expression Omnibus (GEO) [14]. veri bankasından alınan ham veriler kullanılarak yapılan analiz sonucunda ortaya çıkan P-değeri $<0,05$ olan genlerden oluşan gen listeleri kullanılmıştır [15]. (Kullanılan GEO veri setleri - Psoriazis: GSE2737, GSE6710, GSE13355, GSE14905, GSE26866, GSE30999, GSE40263, GSE40333, GSE41662, GSE41745, GSE42632; Romatoid Artrit: GSE1919, GSE10500, GSE55457 ve Atopik Dermatit: GSE16161, GSE27887, GSE32924)

\subsection{Gen - Raportör Metabolit İlişkisi}

İncelenen hastalıklardaki istatistiksel olarak anlamlı Raportör metabolitlerin belirlenebilmesi için genomölçekli metabolik model (HMR2.0) [16] ve bir transkriptom verisindeki tüm genleri dikkate alarak metabolik değişiklikleri belirleyen Raportör metabolit algoritması [17] kullanılmıştır. Bunun için web tabanlı bir kaynak olan BioMet Toolbox'tan [18] yararlanılmış ve P-değeri <0,05 olan raportör metabolitler analiz için seçilmiştir.

\subsection{Raportör Metabolit - Metabolik Yolak Ağı Kurulması}

Her bir hastalık için ayrı ayrı incelenen gen listelerinden elde edilen raportör metabolitler karşılaştırılmış ve her bir hastalığın raportör metabolitlerinin metabolik yolakları MBROLE 2.0 kullanılarak elde edilmiştir [19]. Ayrıca metabolik yolakların bulunması açısından kolaylık göstermesi bakımından Raportör Metabolitler KEGG bileşik isimlerine (KEGG Compound ID) MBROLE 2.0 kullanılarak dönüştürülmüştür.

Hastalıkların Raportör Metabolit - Metabolik Yolak Ağlarının görselleştirilmesi Cytoscape kullanılarak yapılmıştır [20].

\subsection{Raportör Metabolit - Bağırsak Mikrobiatası ilişkisi}

Elde edilen Raportör metabolitler ile insan bağırsak mikrobiyotası arasındaki ilişki Sung ve arkadaşlarının [21] yaptığı çalışma baz alınarak ortaya çıkarılmıştır. İnsan bağırsak mikrobiyotasındaki mikrop türlerinin filumları genomik, kimyasal ve sistemik fonksiyonel bilgileri birleștiren bir veri tabanı kaynağı olan KEGG (Kyoto Genler ve Genomlar Ansiklopedisi) kullanılarak elde edilmiştir [22].

Ayrıca her üç hastalıkta Raportör Metabolitlerle ilintili bağırsak mikrobiyotasının hastalık zenginleștirme analizi web-bazlı Micropattern mikrop seti analiz aracı kullanılarak yapılmıştır [23].

\section{Bulgular}

$\mathrm{Bu}$ çalışmada kompleks üç otoimmün hastalığın (Psoriazis, Romatoid Artrit, Atopik Dermatit) daha önceden yapılmış olan bir çalışmadan elde edilen gen listeleri ve çeşitli omik araçları kullanılarak insan bağırsak mikrobiyotası ile bu hastalıklar arasında bir bağlantı kurulmuştur. Bunun için öncelikle incelenen hastalıkların gen listeleri kullanılarak Raportör metabolit analizi yapılmıștır. Raportör metabolit analizi transkripsiyonel regülasyonu metabolik ağa dâhil ederek canlı bir organizmanın metabolizmasını kapsamlı bir şekilde incelemek ve metabolizma ile genlerin bağlantısını daha ayrıntılı anlayabilmek amacıyla yapılır. Şekil 1'de her bir veri seti için elde edilen Raportör metabolitlerin ve zenginleștirme analizi sonucu elde edilen metabolik yolakların sayısı verilmiştir. Ayrıca burada görüleceği üzere analiz sonucu elde edilen Raportör Metabolitlerin KEGG Bileşik ID'si olmayanlar da vardır. ID'si olmayan raportör metabolitler zenginleștirme analizine dahil edilmediler.

Yapılan Psoriazis Raportör Metabolit analizi sonucunda her veri setinin gen listesi ayrı analize tabi tutulmuş bunun sonucunda en az dokuz gen listesinde (GSE2737, GSE6710, GSE13355, GSE26866, GSE41745, GSE14905, GSE30999, GSE41662) ortak olan yedi Raportör Metabolit (3-hydroxyanthranilate, 3-hydroxy-L-kynurenine, anthranilate, formylanthranilate, Kynurenine, L-formylkynurenine, thymidine) ortaya çıkmıştır.

Her bir veri seti için ayrı olarak listelenen raportör metabolitlerin zenginleştirme analizi sonucu ortaya çlkan ve en az 6 veri setinde bulunan metabolitlerin gruplandırılması da yapılmış ve bunların başlıca üç grupta bulunan metabolik yolaklarla ilgili oldukları ortaya çıkarılmıştır. Bu gruplar a) amino asit metabolizması (Triptofan metabolizması, D-Arjinin ve D-ornitin metabolizması), b) lipit metabolizması (Glycerolipid metabolizması, steroid hormonu) metabolizması, c) karbonhidrat metabolizması (Pentoz fosfat yolu ve galaktoz metabolizması) Öte yandan, 10 veri setinde Amyotrofik lateral skleroz 
(ALS) ve Pirimidin metabolizması yolağının yaygın olduğunu görülmüştür, bunun yanı sıra amino asit metabolizması yolakları (Arjinin ve prolin metabolizması, Alanin, aspartat ve glutamat metabolizması, Taurin ve hippotaurin metabolizması, Triptofan metabolizması, Valin, lösin ve izolösin biyosentezi), karbonhidrat metabolizması yolakları (Pentoz fosfat yolu, Piruvat metabolizması), nükleotid metabolizması yolakları (Pirimidin metabolizması ve Purin metabolizması), çevresel bilgi işleme ile ilgili yolaklar (ABC taşıyıcıları), enerji metabolizması yolakları (oksidatif fosforilasyon) ve boşaltım sistemi ile ilişkili yolak (Proksimal tübül bikarbonat ıslahı) zenginleştirme sonucunda ortaya çlkmıştır.

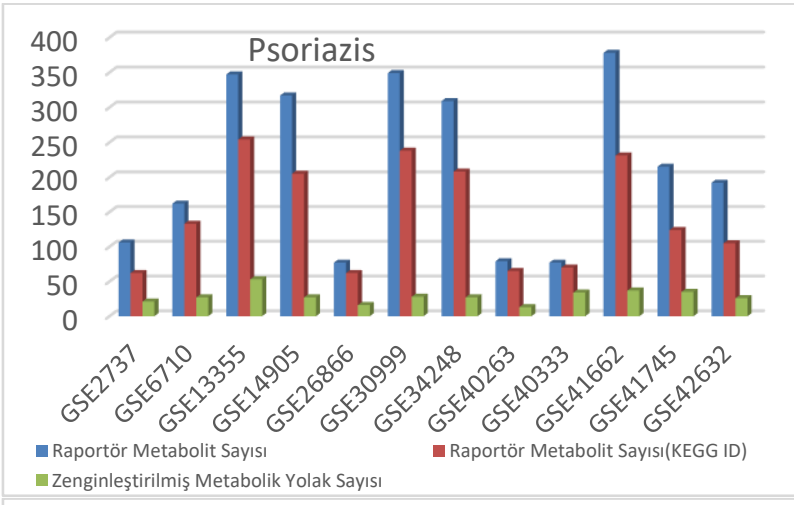

Zenginleştirilmiş Metabolik Yolak Sayısı

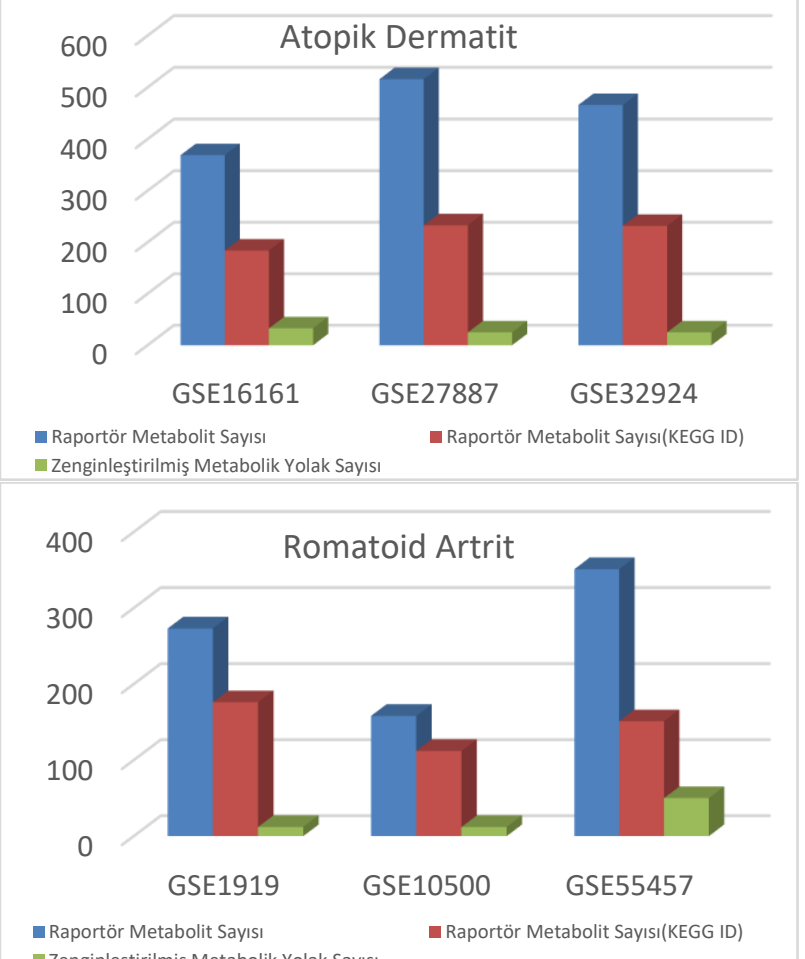

Zenginleștirilmiș Metabolik Yolak Sayıs

Şekil 1. İncelenen hastalıklar için Analiz sonucu elde edilen Raportör metabolit sayısı, KEGG ID'si olan Raportör metabolit sayısı ve Metabolik yolak sayısı

Atopik dermatit veri setlerinin raportör metabolit analizleri, her üç veri setinde de ortak raportör olarak 41 metaboliti ortaya çıkarmıştır. En az iki veri setinin paylaştığl ortak raportör metabolitler ortaya çıkarıldığında ise bu metabolitler genellikle dört grup metabolik yolakla zenginleștirilmiştir. Bu yolaklar: a) lipit metabolizması (Yă̆ asidi biyosentezi, mitokondride yă̆ asidi uzaması, doymamış yağ asitlerinin biyosentezi, yağ asidi metabolizması ve keton cisimlerinin sentezi ve bozunması), b) karbonhidrat metabolizması (Propanoat metabolizması, Glioksilat ve dikarboksilat metabolizması, Sitrat döngüsü (TCA) döngüsü) ve Butanoat metabolizması), c) amino asit metabolizması (Triptofan metabolizması, Valin, lösin ve izolösin ayrışımı ve beta-Alanin metabolizması), d) boşaltım sistemi (Kanal asit sekresyonu toplanması ve Proksimal tübül bikarbonat islahı) şeklinde gruplandırılabilir. $\mathrm{Bu}$ yolakların dıșında enerji metabolizması (oksidatif fosforilasyon) ve nörodejeneratif hastalıklar (Parkinson hastalığı) gibi diğer metabolik yolaklar da ortaya çıkarılmış oldu. Atopik dermatit veri setlerinin metabolik yolak zenginleștirme analizi 8 ortak yolak ortaya çıkarmıştır ve bunlar lipid metabolizmasında (mitokondride yağ asidi uzaması, yă asidi metabolizması ve keton cisimciklerinin sentezlenmesi ve parçalanması), karbonhidrat metabolizmasinda (Glioksilat ve dikarboksilat metabolizması, Propanoat metabolizması ve Piruvat metabolizması), enerji metabolizması (Oksidatif fosforilasyon) ve ksenobiyotik biyodegradasyon ve metabolizmasında (sitokrom P450 ile ksenobiyotiklerin metabolizması) yer alan yolaklardır.

Romatoid artrit veri setlerinin her birinin analizi sonucu her üç veri setinde ortak tek bir raportör metaboliti (10-formil-THF) ortaya çıkartılmıştır. Bu sebeple zenginleștirme analizi yapabilmek için iki veri setinde ortak 34 raportör metabolit kullanılmış ve sonuç itibari ile başlıca dört grup metabolik yolak ortaya çıkarılmıștır: a) lipit metabolizması (Doymamış yağ asitlerinin biyosentezi, Eter lipit metabolizması ve Gliserolipit metabolizması), b) Boşaltım sistemi (Proksimal tübül bikarbonat ıslahı ve Toplama kanalı asit sekresyonu), c) enerji metabolizması (Metan metabolizması, Oksidatif fosforilasyon ve Azot metabolizması), d) karbonhidrat metabolizması (Glioksilat ve dikarboksilat metabolizması, Piruvat metabolizması, Glikoliz/Glukoneojenez, Propanoat metabolizması ve İnositol fosfat metabolizması). Bunların haricinde kofaktör ve vitamin metabolizması (Riboflavin metabolizması) ve amino asit metabolizması (Glutatyon metabolizması) metabolik yolakları ile bağlantılarında istatistiksel olarak anlamlı sonuçlar elde edilmiştir.

İncelenen üç otoimmün hastalığın raportör metabolit - metabolik yolak ağı görseli Şekil 2'de görülmektedir. $\mathrm{Bu}$ üç otoimmün hastalığın tek ortak metabolik yolağı oksidatif fosforilasyon olarak karşımıza çıkmaktadır.

Raportör metabolit analizinden sonra bu metabolitlerin bağırsak mikrobiyotası ile olan ilişkilerinin ortaya çıkarılması için yapılan analiz sonucunda bu hastalıklarda önemli olduğu ortaya çıkan mikrobiyal türlerin sayısı ve bu mikrobiyotanın 
zenginleștirme analizi sonucu ortaya çlkan diğer hastalıklar Şekil 3'te görülmektedir.

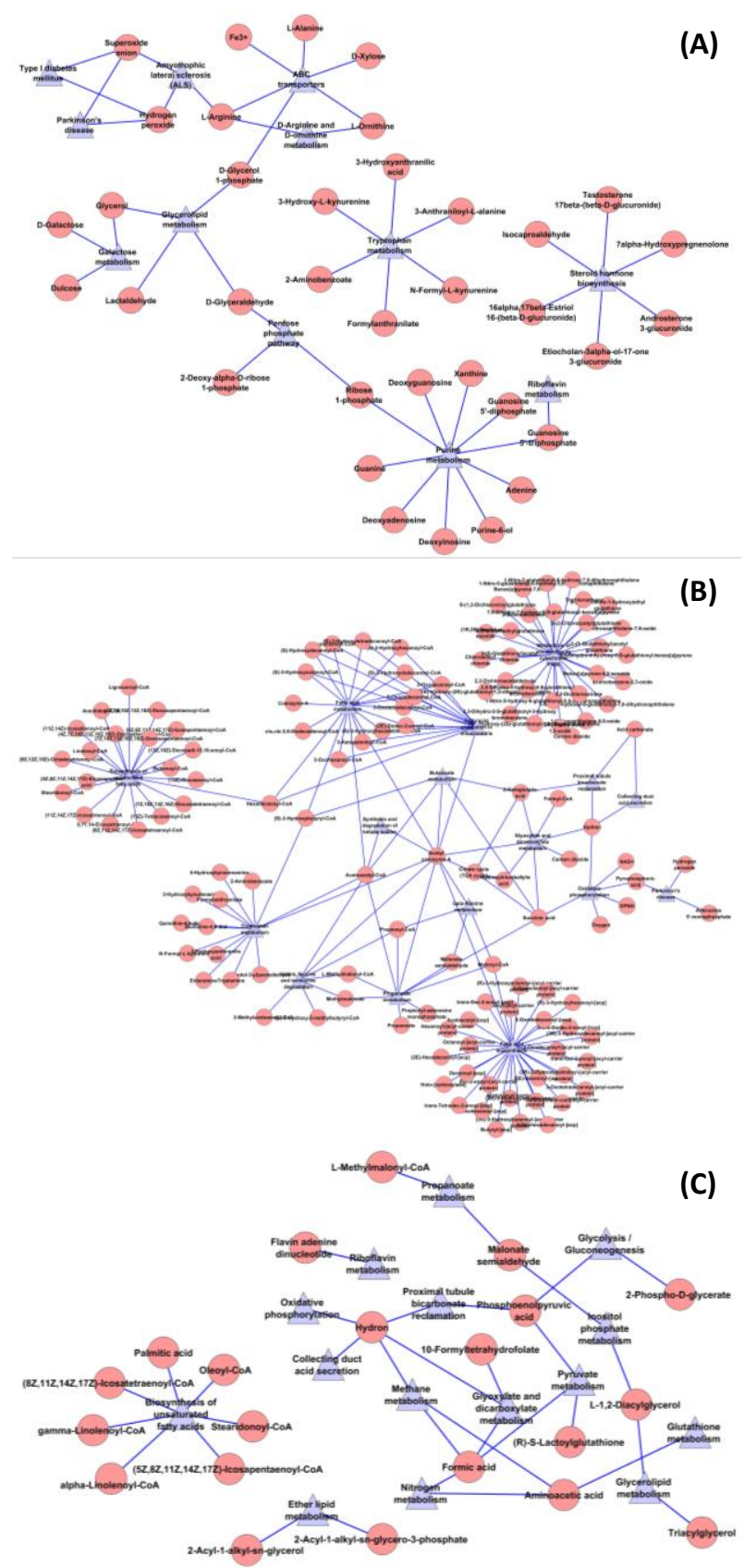

Şekil 2. A) Psoriazis, B) Atopik Dermatit, C) Romatoid Artrit Metabolit-Metabolik Yolak Ağı (P değeri < 0,05; Üçgen: Metabolik Yolak, Daire: Metabolit)

Psoriazis Raportör Metabolitleri ile İnsan Bağırsak Mikrobiyotası arasındaki ilişkiyi belirleyebilmek için yapılan analizlerde dokuz tane veri setinde ortak bulunan mikrobiyota listelenmiş ve burda en çok mikrobiyal türün Firmicutes-Bacilli filumunda (33 adet) olduğu ortaya çıkmıştır. Atopik dermatit ve Romatoid artrit için yapılan analizlerde ise veri setlerinde ortak bulunan mikrobiyota listelenmiș ve bu iki hastalıkta da en çok mikrobiyal türün Firmicutes-Bacilli ( sırasıyla 47 ve 48 adet) filumunda olduğu ortaya çıkmıştır. Bu iki hastalığın mikrobiyal gruplarının Psoriasiz mikrobiyal gruplarından farkı burada Tenericutes filumundan Psoriazis'ten (1 adet) daha fazla tür bulundurmalarıdır (20'şer adet).

$\mathrm{Bu}$ hastalıklarla ilintili bağırsak mikrobiyotasının hastalık zenginleștirme analizi sonucunda aynı bağırsak mikrobiyotasının egzema, ileal crohn hastalığı, crohn hastalığı ve akciğer sirozunda da farklılaşma gösterdiği belirlenmiştir.

İncelenen her üç hastalığın mikrobiyal türlerinin filumları incelendiğinde (Şekil 4) Firmicutes, Deltaproteobacteria, Bacteriodetes ve Actinobacteria filumlarındaki türleri bu hastalıklarda yoğun olarak görülmektedir. Burada bir başka dikkat çeken husus ise Tenericutes filumunun Atopik dermatit ve Romatoid artrit'te yoğun olarak görüldügü fakat Psoriazis'te çok fazla çeşitlilik göstermediğidir. Şekil 5 incelenen hastalıklardaki ortak mikrobiyal türleri ve onların filumlarını göstermektedir.

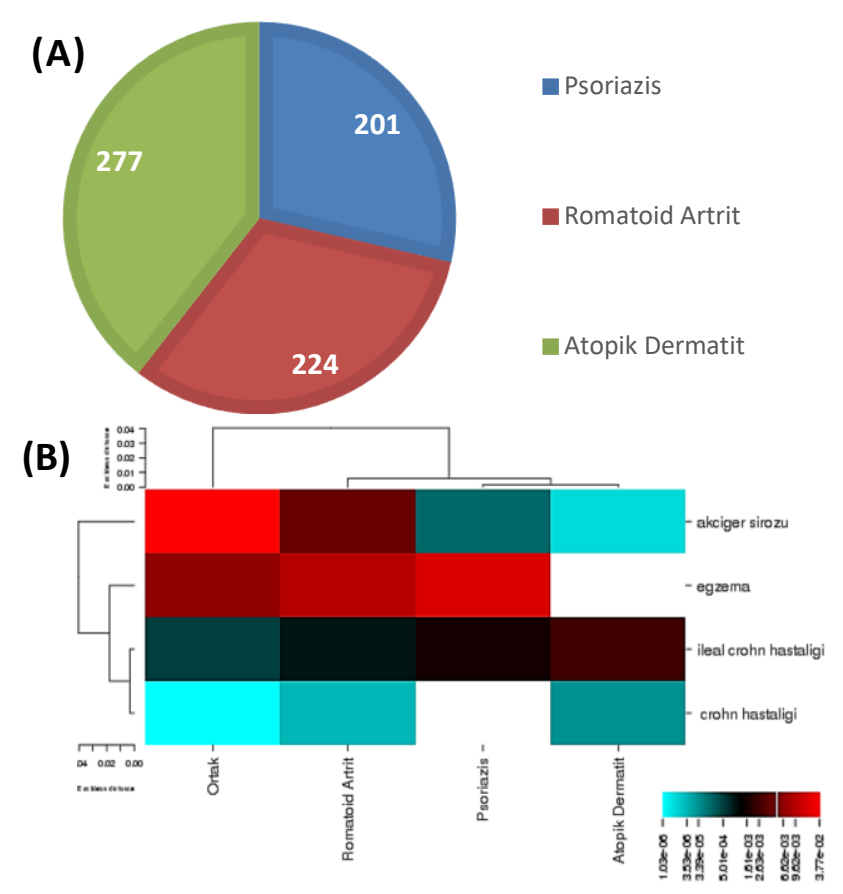

Şekil 3. A) Psoriazis, Romatoid Artrit ve Atopik Dermatit hastalıklarında bulunan bağırsak mikrobiyotasındaki mikrobiyal tür sayısı B) Hastalık Zenginleștirme Analizi

Ortak mikrobiyal türler ve onların filumları incelendiğinde Firmicutes-Bacilli filumuna ait türlerin nisbi olarak fazlalık gösterdiği ortaya çıkmaktadır (Şekil 5). Bu grubu Firmicutes - clostridia ve Bacterioidetes takip etmektedir.

Sağlıklı insan bağırsak mikrobiyotasındaki patojenik türleri belirleyebilmek için İnsan Mikrobiyom Projesi Konsorsiyumu'nun [24] oluşturduğu listeden faydalanılarak incelenen hastalıklar için bir patojenik tür şeması oluşturulmuştur (Şekil 6). Oluşturulan şemaya göre incelenen hastalıklardaki ortak mikrobiyal türlerin patojen olanlarının aynı zamanda her üç hastalığın kesişim kümesi olduğu görülmektedir. Burada en çok Firmicutes-bacilli filumuna ait patojenik türler olduğu gözlemlenmektedir. 


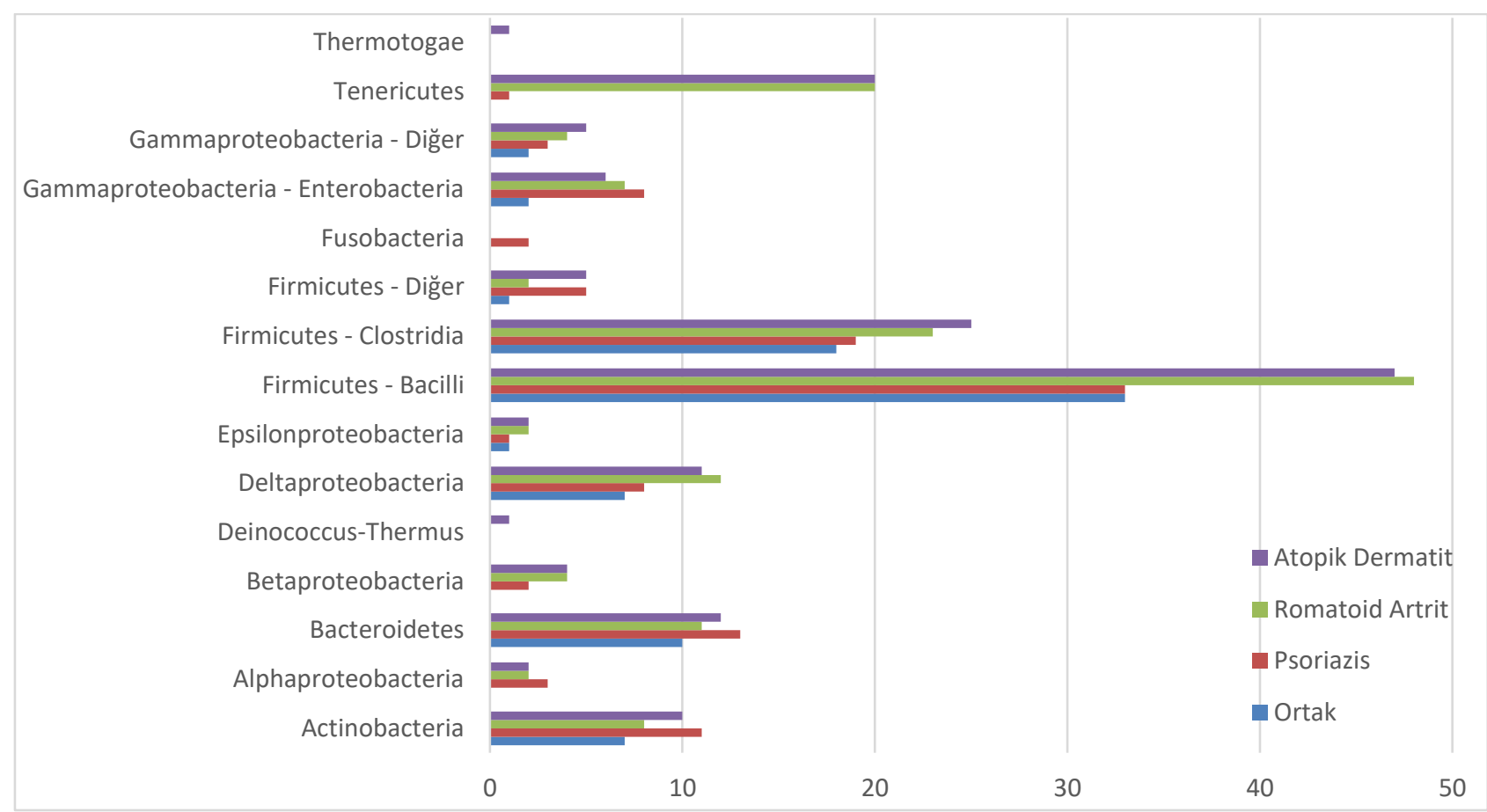

Şekil 4. İncelenen hastalıklardaki mikrobiyal türlerin ait olduğu fila

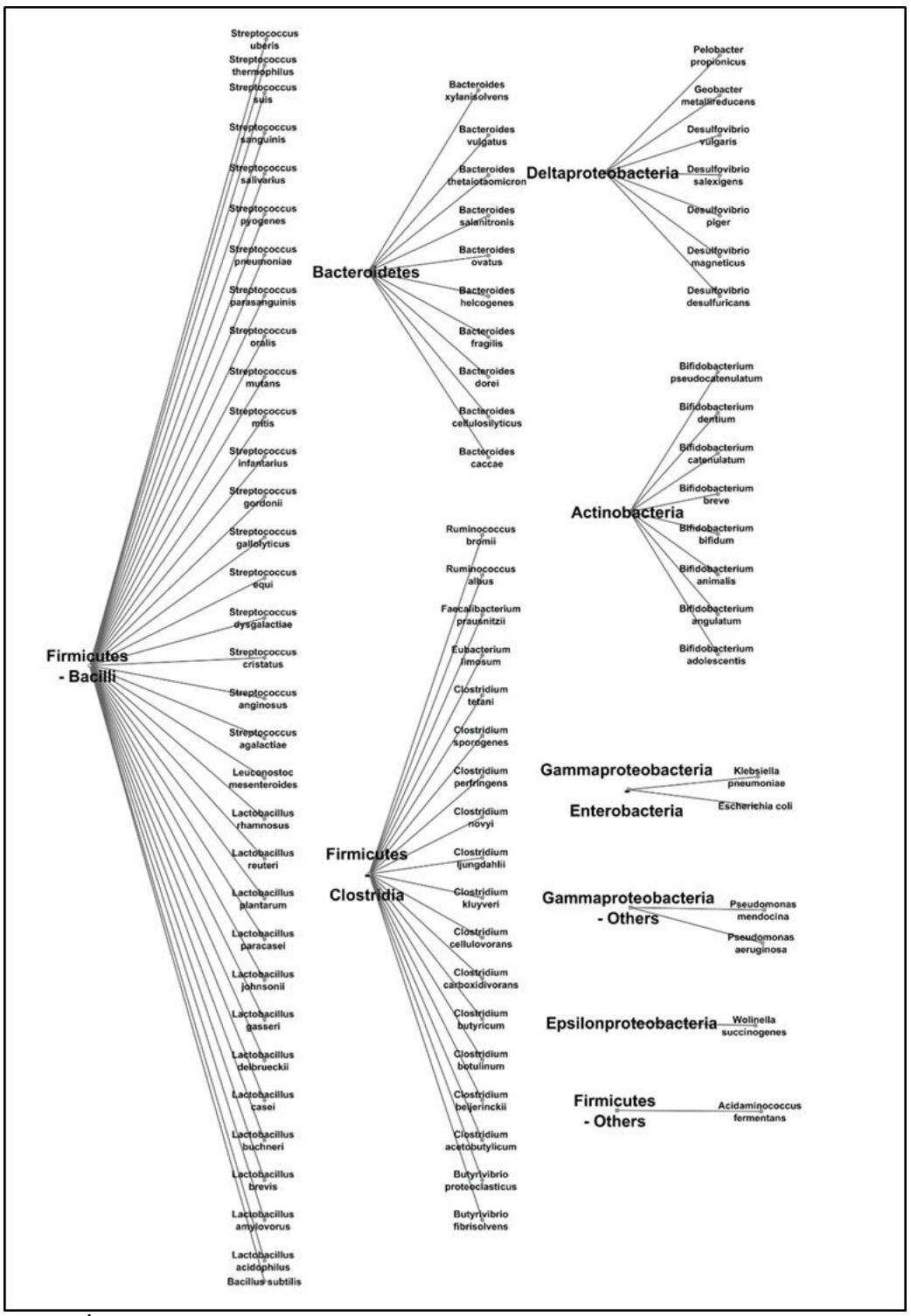

Şekil 5. İncelenen hastalıklarda ortak olan mikrobiyal türler ve onların filumları 


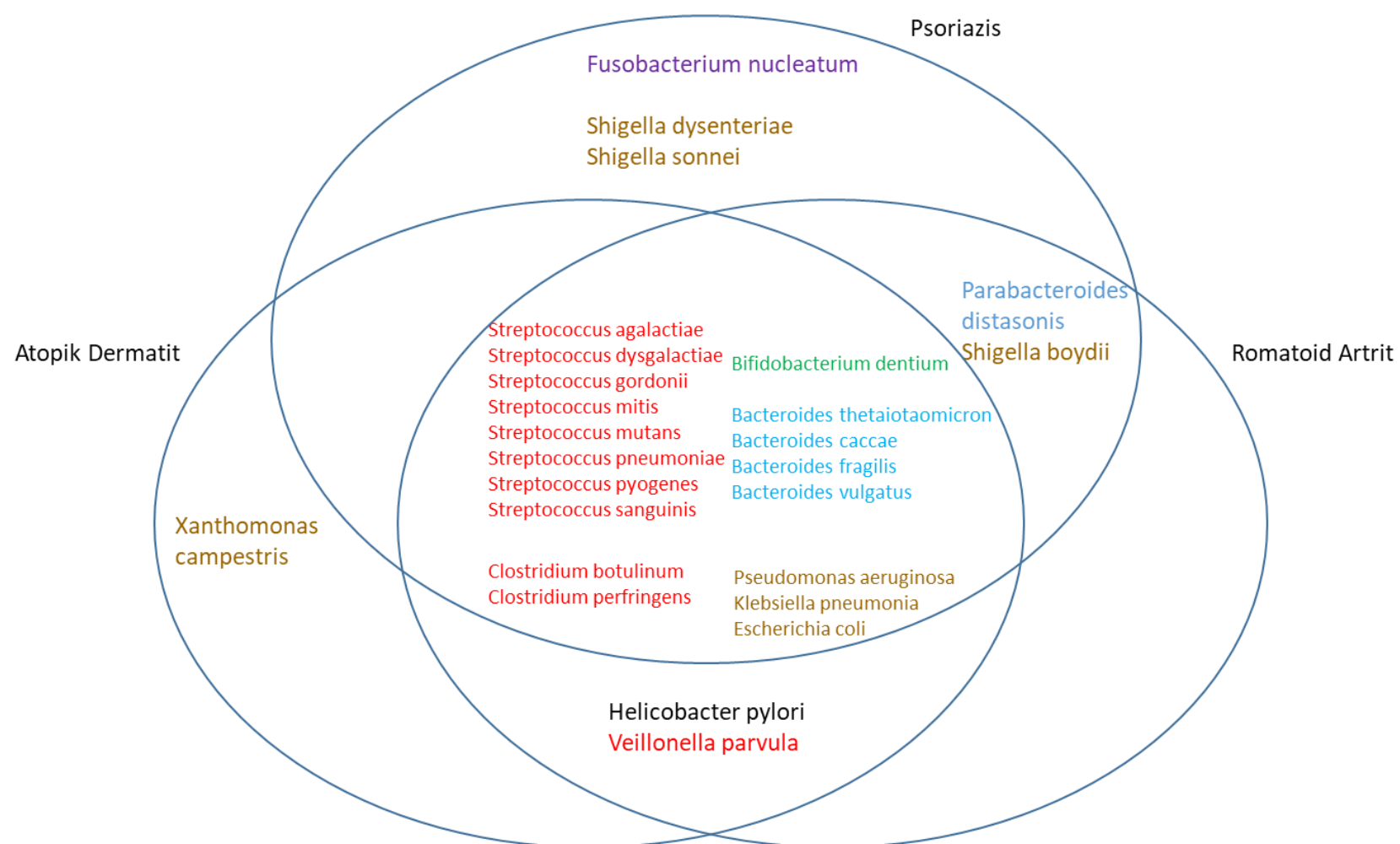

Şekil 6. İncelenen hastalıklarda patojenik türler ve filumları (Bactoriodete: mavi, Actinobacteria: yeșil, Gammaproteobacteria: kahverengi, Firmicutes: kırmızı, Fusobacteria: mor, Epsilonproteobacteria: siyah)

\section{Tartışma ve Sonuç}

Bu çalışmada birer otoimmün hastalık olan Psoriazis, Atopik Dermatit ve Romatoid Artrit hastalıklarının farklı gen anlatımına sahip gen listeleri analiz edilerek bu genleri metabolizma ile ilişkilendirecek raportör metabolitler ortaya çıkarılmıştır. Daha sonra insan bağırsak mikrobiyotası ile bu metabolitler arasında bir bağlantı kurulmuştur.

Psoriazis Raportör Metabolit analizi sonucu ortaya çıkan ortak sekiz metabolitin altısı triptofan metabolizması ile ilgilidir. Triptofan metabolizma yolağı indoleamine 2,3-dioksijenaz (IDO) enzimi ve kynureninin (KYNU) üretimi ile immün baskılanmayı teşvik eder. Psoriazis gibi bağışıklık sistemi hastalıklarında IDO ve KYNU gibi triptofan metabolizması enzimlerinin yukarı regüle oldukları bilinmektedir [25].

Atopik dermatit veri setlerinin raportör metabolit analizleri sonucu ortaya çıkan 41 metabolitten 17'si Sitokrom P450 ile ksenobiotik metabolizmasında yer almaktadır. Bir ksenobiyotik, organizmada doğal olarak üretilmeyen veya dişsal bir organizma içinde bulunan kimyasal bir maddedir [26]. Sitokrom P450 enzimleri çeşitli metabolik ve biyosentez süreçlerinde yer alan ve çoğu ksenobiyotik metabolizması ile ilişkili olan başlıca metabolize edici enzimlerdendir [27].

İncelenen üç otoimmün hastalığın ortak yolağı olan proksimal tübül bikarbonat geri kazanılması yolağı vücut asit-baz dengesi için önemli bir yolaktır. Kandaki asit-baz dengesini korumak için en önemli tampon, karbonik asit-bikarbonat tamponudur. Her gün, böbrekler $180 \mathrm{~L}$ kan filtreler, bu da ana kan tamponlarından olan bikarbonatın yaklaşık 4,300 mmol miktarına denk gelir. Böbrekteki fonksiyonel birim her bir nefronun ana resorptif segmenti olan proksimal tübül tüm filtrelenmiş su, sodyum ve klorürün yaklaşık üçte ikisini emer. Her bir hücredeki hücre döngüsünün kontrolünden kas kasılmasına kadar her bir hücresel ve bedensel işlev pH'a bağlıdır. $\mathrm{Bu}$ sebeple hücre içi $\mathrm{pH}$ ve $\mathrm{pH}$ regülasyonunun bağlı olduğu tüm vücut asit-baz homeostazının düzenlenmesi büyük önem taşımaktadır [28].

İncelenen tüm hastalıklarda tek ortak metabolit olan NAD+, glikoliz, oksidatif fosforilasyon ve fermentasyon ile ilişkili reaksiyonlarda önemli bir rol oynamaktadır. Bu üç hastalığın tek ortak metabolik yolağı olan oksidatif fosforilasyon ise, hayvanların ve bitkilerin yaşamını desteklemek için ATP'nin kullanılması, metabolik homeostazın ayarlanması ve sürdürülmesinden sorumludur. Metabolizmada oksidatif fosforilasyonun rolünü anlamak, metabolizmayı anlamak için gereklidir. Özellikle vücudumuzdaki iskelet kasları için oksidatif fosforilasyon önem arz etmektedir [29]. Bu metabolik yolağın incelenen üç otoimmün hastalıkta da ortak çıkmasının nedeni bunların artrit bağlantılı hastalık olmalarından kaynaklanıyor olabilir. Aynı zamanda oksidatif fosforilasyon diğer metabolik yolaklar ile uyumlu bir şeklide çalıştığ metabolizmasını regüle eden sistem etkin halde çalışıyor demektir. Dolayısıyla bu hastalıklarda enerji metabolizmasının regülasyonunda bir sorun olduğu anlaşılmaktadır. 
Yapılan bu çalışmada ortaya çıkan mikrobiyal türler daha çok Firmicutes filumundan olup bu filum bakteriyel filada en çok elemanı olan grup olarak bilinir. Bu üst grup Bacillus, Listeria, Staphylococcus, Streptococcus, Enterococcus ve Clostridium gibi birçok bilinen cinsi içerir. Bunun yanısıra Firmicutesclostridia ve Bactoriodetes filumlarinda olan mikrobiyal türler de Psoriazis hastalığında yoğunluk göstermektedir. Yakın zamanlarda yapılan çalışmalar ile Psoriazis ve insan mikrobiyotası arasındaki ilişkiyi aydınlatma çabaları hız kazanmıştır. Kutanöz mikrobiyom ile ilgili yapılmış olan çalışmalar Psoriazis hastalarında kontrollere kiyasla Streptococcus'un artan nispi bolluğuna işaret etmektedir. Ayrıca bağırsak mikrobiyotasında, Psoriazisli bireylerde, sağlıklı kontrollere kiyasla, Firmicutes ve Bacteroidetes oranının bozulduğu ortaya çıkmaktadır. Actinobacteria, Psoriazis hastalarında sağlıklı bireylere göre nispeten az temsil edilmiştir [30, 31]. Geçmiş çalışmalara paralel olarak yapılmış olan mevcut çalışmada Actinobacteria filumunun türlerinin Psoriazis'te daha az bulunduğu ortaya çıkarılmıştır. Yakın zamanda yapılmış olan çalışmalarda Psoriazis ile insan bağırsak mikrobiyotasının yanı sıra cilt mikrobiyotası ile ilgili de ilişki ortaya çıkarılmıştır ancak yapılmış olan çalışma sadece insan bağırsak mikrobiyotası ile sınırlandırılmıştır. Ancak unutulmamalıdır ki bağırsak mikrobiyotası ile cilt mikrobiyotası arasında ortak türler bulunulmaktadır. Geçmişte yapılmış olan çalışmalarda Tenericutes filumunda olan bakterilerin Crohn hastalığında nispi azalma gösterdiği saptanmıștır ancak Psoriazis, Atopik dermatit ve Romatoid artrit ile henüz bir ilişkilendirme yapılmamıștır [32].

Mikrobiyota zenginleştirme analizi sonucu ortaya çıkan hastalıklardan biri egzemadır. Atopik dermatit egzemanın bir türüdür. Dolayısıyla ortak mikrobiyota çıkması olağandır. Crohn hastalığı bir inflamatuar bağırsak hastalığıdır (IBD). Karın ağrısına, şiddetli diyare, yorgunluğa, kilo kaybına ve yetersiz beslenmeye yol açabilen bir hastalık olan Crohn hastalığı sindirim sisteminde iltihaplanmaya neden olabilir. İleal Crohn ise Crohn hastalı̆̆ının bir formu olup ileum (ince bağırsağın alt kısmı) ve kolonda irritasyona ve iltihaba neden olur. Hem doğuştan gelen hem de adaptif immünitenin IBD'de kronik inflamasyonu tetiklemede ve sürdürmede önemli bir rol oynadı̆̆ görülmektedir. Bu sebeple tedavisinde romatoid artrit, ankilozan spondilit ve psoriazis gibi diğer immün aracılı hastalıklarla benzer terapötik stratejileri kullanılmaktadır. Psoriazis'in, Crohns'lu hastalarda genel populasyona göre yaklaşık sekiz kat daha yüksek bir sıklıkta görüldüğü bilinmektedir. Ancak bunun sebebi daha çözümlenememiştir [33]. Yapılmış olan bu çalışmaya göre bu hastalıkların ortak yönünün insan bağırsak mikrobiyotasındaki ortak mikrobiyal türlerin düzensizliği olarak izah edilebilir. Romatoid artrit ve Psoriazis'in karaciğer fibrozisi ve siroz ile olan ilişkisinin bu hastalıklarda kullanılan ilaçlara bağlı olduğu söylenmektedir [34]. Ancak yapılan çalışmada da görüldüğü üzere bu ilişkinin yalnızca kullanılan ilaçlar ile sınırlı kalmayıp bağırsak mikrobiyotasında olan benzer değișikliklerden de kaynaklanabileceği ortaya konmaktadır.

Yakın zamanda yapılmış olan çalışmalar mevcut çalışmada olduğu gibi Firmicutes, Deltaproteobacteria, Bacteriodetes ve Actinobacteria filumlarınının mikrobiyal türlerinin bu hastalıklarda yoğun olduğu yönündedir ki bu çalışmalar mevcut analiz sonuçlarını doğrular niteliktedir [35].

Mikrobiyota tarafından türetilmiş karbon ve azot kaynakları patojenik bakteriler tarafından kendi büyümelerini arttırmak için besin maddeleri ve düzenleyici sinyaller olarak kullanılırlar. Bu bakteriler enflamasyonu sağlayarak bağırsak ortamını değiștirir ve çoğalmalarını sürdürebilmek için solunum ve metal alımı için özel sistemler kullanırlar. Mikrobiyota, patojenik türlerin kolonileşmesine karşı direnç geliştirebilir fakat hastalıklardan kaynaklı mikrobiyotadaki değișiklikler, patojenik bakteriler tarafından enfeksiyonun artıșına sebebiyet verebilir [36]. Bu sebeple mikrobiyota, konakçı ve patojenik bakteriler arasındaki etkileşimlerin anlaşılması, hastalıklar için bir çözüm geliştirebilmek açısından önemlidir.

Yapılmış olan çalışma insan bağırsak mikrobiyotasının kompleks otoimmün hastalıklarda bir rolünün olduğunu göstermektedir. Bu çalıșma ayrıca otoimmün bir hastalığın mekanizmasını anlayabilmek için sadece genler - proteinler, bunlar arasındaki etkileşimler ve sinyal yolaklarındaki görevleri değil bunların yanında metabolitler, mikrobiyota ve patojen grupların da detaylıca incelenip analiz edilmesi gerektiğini göstermektedir. Bu konuda yapılmış olan çalışmalar veri yetersizliğinden de kaynaklı olarak az olmasına rağmen sekanslama teknolojilerindeki gelişmeler ile paralel olarak yakın zamanda bir artış beklenmektedir.

\section{Kaynakça}

[1] Ursell, L.K., Metcalf, J.L., Parfrey, L.W. Knight, R., 2012. Defining the human microbiome. Nutrition reviews, 70(suppl_1), S38-S44.

[2] Levy, M., Thaiss, C.A. Elinav, E., 2016. Metabolites: messengers between the microbiota and the immune system. Genes \& development, 30(14), 1589-1597.

[3] Li, B., Selmi, C., Tang, R., Gershwin, M.E. Ma, X., 2018. The microbiome and autoimmunity: a paradigm from the gut-liver axis. Cellular \& molecular immunology. doi: 10.1038/cmi.2018.7.

[4] Vaughn, A.R., Notay, M., Clark, A.K. Sivamani, R.K., 2017. Skin-gut axis: The relationship between intestinal bacteria and skin health. World Journal of Dermatology, 6(4), 52-58. 
[5] Rooks, M.G. Garrett, W.S., 2016. Gut microbiota, metabolites and host immunity. Nature Reviews Immunology, 16(6), 341.

[6] Fraser, A.G. Marcotte, E.M., 2004. A probabilistic view of gene function. Nature genetics, 36(6), 559.

[7] Beebe, K., Sampey, B., Watkins, S.M., Milburn, M. Eckhart, A.D., 2014. Understanding the apothecaries within: the necessity of a systematic approach for defining the chemical output of the human microbiome. Clinical and translational science, 7(1), 74-81.

[8] Braun, P., Rietman, E. Vidal, M., 2008. Networking metabolites and diseases. Proceedings of the National Academy of Sciences, 105(29), 98499850.

[9] Perera, G. K., Di Meglio, P., Nestle, F. O. 2012. Psoriasis. Annual Review of Pathology: Mechanisms of Disease. 7:385 (2012), 422.

[10] Orozco, G., Rueda, B. Martin, J., 2006. Genetic basis of rheumatoid arthritis. Biomedicine \& Pharmacotherapy, 60(10), 656-662.

[11] Gough S.C., Simmonds M.J. 2007. The HLA Region and Autoimmune Disease: Associations and Mechanisms of Action. Curr Genomics. 2007;8(7):453-65.

[12] Hamilton, J.D., Suárez-Fariñas, M., Dhingra, N., Cardinale, I., Li, X., Kostic, A., Ming, J.E., Radin, A.R., Krueger, J.G., Graham, N., Yancopoulos, G.D., 2014. Dupilumab improves the molecular signature in skin of patients with moderate-tosevere atopic dermatitis. Journal of Allergy and Clinical Immunology, 134(6), 1293-1300.

[13] Bieber, T. 2010. Atopic Dermatitis. Annuals of Dermatology. 22(2), 125-137.

[14] Barrett, T., Wilhite, S.E., Ledoux, P., Evangelista, C., Kim, I.F., Tomashevsky, M., Marshall, K.A., Phillippy, K.H., Sherman, P.M., Holko, M., Yefanov, A., 2012. NCBI GEO: archive for functional genomics data sets-update. Nucleic acids research, 41(D1), D991-D995.

[15] Sevimoglu, T. 2015. Using Systems Based Models To Uncover The Disease Network Of Psoriasis And Its Associations With Other AutoimmuneRelated Diseases. Marmara Üniversitesi, Fen Bilimleri Enstitüsü, Doktora Tezi, İstanbul.

[16] Mardinoglu, A., Agren, R., Kampf, C., Asplund, A., Uhlen, M. Nielsen, J., 2014. Genome-scale metabolic modelling of hepatocytes reveals serine deficiency in patients with non-alcoholic fatty liver disease. Nature Communications, 5, 3083.

[17] Agren, R., Liu, L., Shoaie, S., Vongsangnak, W., Nookaew, I. Nielsen, J., 2013. The RAVEN toolbox and its use for generating a genome-scale metabolic model for Penicillium chrysogenum. PLoS computational biology, 9(3), p.e1002980.

[18] Garcia-Albornoz, M., Thankaswamy-Kosalai, S., Nilsson, A., Väremo, L., Nookaew, I. Nielsen, J., 2014. BioMet Toolbox 2.0: genome-wide analysis of metabolism and omics data. Nucleic acids research, 42(W1), W175-W181.

[19] López-Ibáñez, J., Pazos, F. Chagoyen, M., 2016. MBROLE 2.0-functional enrichment of chemical compounds. Nucleic acids research, 44(W1), W201-W204.

[20] Shannon, P., Markiel, A., Ozier, O., Baliga, N.S., Wang, J.T., Ramage, D., Amin, N., Schwikowski, B. Ideker, T., 2003. Cytoscape: a software environment for integrated models of biomolecular interaction networks. Genome research, 13(11), 2498-2504.

[21] Sung, J., Kim, S., Cabatbat, J.J.T., Jang, S., Jin, Y.S., Jung, G.Y., Chia, N. Kim, P.J., 2017. Global metabolic interaction network of the human gut microbiota for context-specific community-scale analysis. Nature communications, 8, 15393.

[22] Kanehisa, M., Furumichi, M., Tanabe, M., Sato, Y. and Morishima, K., 2016. KEGG: new perspectives on genomes, pathways, diseases and drugs. Nucleic acids research, 45(D1), D353-D361.

[23] Ma, W., Huang, C., Zhou, Y., Li, J. Cui, Q., 2017. MicroPattern: a web-based tool for microbe set enrichment analysis and disease similarity calculation based on a list of microbes. Scientific reports, 7, 40200.

[24] The Human Microbiome Project Consortium, 2012. Structure, function and diversity of the healthy human microbiome. Nature volume 486, pages 207-214 (14 June 2012).

[25] Harden, J.L., Lewis, S.M., Lish, S.R., SuárezFariñas, M., Gareau, D., Lentini, T., JohnsonHuang, L.M., Krueger, J.G. Lowes, M.A., 2016. The tryptophan metabolism enzyme L-kynureninase is a novel inflammatory factor in psoriasis and other inflammatory diseases. Journal of Allergy and Clinical Immunology, 137(6), 1830-1840.

[26] Croom, E., 2012. Metabolism of xenobiotics of human environments. In Progress in molecular biology and translational science, 112, 31-88.

[27] Anzenbacher, P. and Anzenbacherova, E., 2001. Cytochromes P450 and metabolism of xenobiotics. Cellular and Molecular Life Sciences CMLS, 58(5-6), 737-747.

[28] Skelton, L.A., Boron, W.F. and Zhou, Y., 2010. Acidbase transport by the renal proximal tubule. Journal of nephrology, 23(0 16), p.S4.

[29] Wilson, D.F., 2017. Oxidative phosphorylation: regulation and role in cellular and tissue metabolism. The Journal of physiology, 595(23), 7023-7038. 
[30] Yan, D., Issa, N., Afifi, L., Jeon, C., Chang, H.W. and Liao, W., 2017. The role of the skin and gut microbiome in psoriatic disease. Current dermatology reports, 6(2), 94-103.

[31] Benhadou, F., Mintoff, D., Schnebert B., Thio, H. B., 2018. Psoriasis and Microbiota: A Systematic Review. Diseases. 6, 47.

[32] Imhann, F., Vila, A.V., Bonder, M.J., Fu, J., Gevers, D., Visschedijk, M.C., Spekhorst, L.M., Alberts, R., Franke, L., Van Dullemen, H.M. Ter Steege, R.W., 2018. Interplay of host genetics and gut microbiota underlying the onset and clinical presentation of inflammatory bowel disease. Gut, 67(1), 108-119.

[33] Fiorino G., Omodei P. D. 2015. Psoriasis and Inflammatory Bowel Disease: Two Sides of the
Same Coin?, Journal of Crohn's and Colitis. 9(2015)(9), 697-698.

[34] Lindsay, K., Fraser, A.D., Layton, A., Goodfield, M., Gruss, H. Gough, A., 2009. Liver fibrosis in patients with psoriasis and psoriatic arthritis on long-term, high cumulative dose methotrexate therapy. Rheumatology, 48(5), 569-572.

[35] Negi, S., Singh, H. Mukhopadhyay, A., 2017. Gut bacterial peptides with autoimmunity potential as environmental trigger for late onset complex diseases: In-silico study. PloS one, 12(7), p.e0180518.

[36] Bäumler, A.J. and Sperandio, V., 2016. Interactions between the microbiota and pathogenic bacteria in the gut. Nature, 535(7610), 85. 